\title{
VIRGILIO MATTONI Y LA HERMANDAD DE LA MACARENA DE SEVILLA
}

\section{VIRGILIO MATTONI WORKS FOR THE BROTHERHOOD OF LA MACARENA IN SEVILLE}

\author{
ANDRÉs LuQue TERUEL \\ Universidad de Sevilla, España \\ luquete@us.es
}

\begin{abstract}
Virgilio Mattoni fue un importante pintor sevillano, activo en un amplio período de tiempo, comprendido entre el último tercio del siglo XIX y el inicio de la tercera década del siglo XX. Su actividad académica e intelectual fue pareja a su capacidad como pintor. Colaborador habitual de la Hermandad de la Macarena como asesor artístico, intervino junto al escultor Emilio Pizarro en la restauración y posterior reforma del misterio de la Sentencia de Cristo y la restauración de la Virgen de la Esperanza (Macarena), que aquí se analizan de modo pormenorizado. De la misma época y contexto es la pintura inédita presentada y estudiada por primera vez en este artículo.

Palabras Claves: Macarena, Pintura de Historia, Arte realista, Arte simbolista, pintura sevillana siglo XIX.
\end{abstract}

This article is about the Spanish painter Virgilio Mattoni and his intervention in some preservatives or reforms in sculptural Sentence group and famous sculpture of Esperanza Virgin, in 1880 to 1898. The papers and formal analysis allow establish his contribution with Emilio Pizarro sculptor, and the concrete last form of this artistic work. In this context, Virgilio Mattoni painted The Esperanza Virgin come out of the San Gil Church, in 1896, unpublished painting present here.

Keywords: Macarena, History painting, Realistic Art, Symbolic Art, Spanish painting.

El pintor Virgilio Mattoni asesoró a la Hermandad de la Macarena en una serie de intervenciones sobre sus imágenes titulares y los pasos en los que éstas salían en procesión en las dos últimas décadas del siglo XIX. Sus opiniones no fueron requeridas por casualidad, se trataba de un hombre culto e involucrado con la conservación del patrimonio nacional. En esa época pintó una escena sobre la salida en procesión de la Virgen de la Esperanza, hasta ahora inédita, que ha de verse en relación con los trabajos anteriores.

Nació en Sevilla el día treinta de enero de 1842, en una época crucial para la Hermandad de la Macarena, recién reformada por un Hermano Mayor 
fundamental para su futuro inmediato, Juan Nepomuceno Sarramián; y casi tres décadas antes de la aparición, trascendental, de Juan Manuel Rodríguez Ojeda. Su sólida formación estuvo avalada por un largo período de aprendizaje en la Escuela Provincial de Bellas Artes de Sevilla ${ }^{1}$, en la que ingresó en el curso de 1856-57 y en la que permaneció hasta el de 1867-68. Durante esos doce años fue discípulo de Joaquín Domínguez Bécquer y de Eduardo Cano de la Peña, con los que conoció las tradiciones narrativas y literarias tardo y postrománticas, y el realismo historicista, respectivamente. No abrió su primer estudio, en los Reales Alcázares de Sevilla, hasta el año 1870. Una estancia en Roma, documentada entre 1872 y 1875 , ya con treinta años cumplidos, lo reafirmó en los principios realistas y lo abrió a nuevos horizontes intelectuales, sobre todo en lo que concierne a la consciencia del valor del patrimonio y las necesidades de conservación del mismo. En el mes de diciembre del último año citado volvió a Sevilla y se instaló en un nuevo estudio en el entorno de los Reales Alcázares, en concreto en el Patio de Banderas, al que siguieron otros en las calles Cruces y Maese Rodrigo.

$\mathrm{Su}$ primer reconocimiento oficial, la Medalla de Plata en la Exposición Regional de Cádiz del año 1879, fue justo antes de su primera colaboración con la Hermandad de la Macarena en la restauración del misterio de la Sentencia, en 1880. Poco después fue propuesto para la Segunda Medalla de la Exposición Nacional de Bellas Artes, en 1881, por el cuadro Las Termas de Caracalla, pintado en Roma en el período antes indicado. Ese mismo año asesoró en la intervención documentada sobre la Virgen de la Esperanza. Fue una de sus primeras aportaciones en el ámbito patrimonial, pronto prestigiadas con importantes nombramientos y responsabilidades.

Ingresó como miembro de la Real Academia de Bellas Artes de San Fernando de Madrid en la sesión del día veintiséis de abril de 1886, y, en consecuencia, desde ese momento formó parte de la Comisión Provincial de Monumentos, en la que mostró un gran interés por la conservación del patrimonio local y regional. Además, desde 1887 fue Académico Numerario de la Provincial de Bellas Artes de Sevilla, en sustitución del pintor Jiménez Aranda. Su involucración en los temas de Patrimonio fue tan intensa como su actividad pictórica, por la que obtuvo un nuevo galardón, la Medalla de Segunda Clase en la Exposición Nacional de 1887, con el cuadro de orden colosal Las postrimerías del Rey San Fernando, depositado en los Reales Alcázares.

Su dedicación a la docencia en la Escuela Provincial de Bellas Artes también fue muy productiva, primero como Ayudante Numerario de la Cátedra de Dibujo de figura. En la doble condición de conservador y artista creativo, realizó un detallado dibujo de la Virgen de los Reyes bajo un palio de cajón, en 1891; y asesoró en la restauración de la Virgen de Valme, para la que realizó distintos proyectos

${ }^{1}$ PÉREZ CALERO, Gerardo: Virgilio Mattoni; Sevilla, Excma. Diputación Provincial de Sevilla, 1977, pp. 13-16. 
en 1894. En ese contexto de compromiso con los valores culturales y patrimoniales solicitó la recuperación del título de Santa Isabel de Hungría de Sevilla para la Academia Provincial de Bellas Artes, en 1896. Ese mismo año sustituyó al escultor madrileño Pedro Domínguez López como Secretario de la Escuela Provincial de Bellas Artes; y pintó la interesante obra titulada La Virgen de la Esperanza saliendo de la Iglesia de San Gil.

Gozaba de un sólido prestigio cuando intervino como asesor de la profunda remodelación del misterio de la Sentencia de la Hermandad de la Macarena, en 1898. Después consiguió la Cátedra de Aplicaciones del Dibujo Artístico a las Artes Decorativas, en 1900; la Cátedra de Composición Decorativa, en 1904; la Cátedra de Estudio de las Formas de la Naturaleza y del Arte, en 1906; y la plaza de Profesor Numerario, en 1907; e incluso la Dirección Interina de la Escuela de Bellas Artes, en 1917, a la edad de setenta y cinco años.

Aquélla fue su última colaboración documentada con la Hermandad de la Macarena, después lo hizo con otras hermandades, por ejemplo, intervino como asesor en el nuevo revestimiento del armazón barroco del paso de Jesús Nazareno de la Hermandad del Silencio, al que diseñó los faroles que en la actualidad iluminan el paso del Nazareno de la Misericordia de la Hermandad de las Siete Palabras, en 1913. Igualmente, asesoró en la restauración y la nueva distribución de las imágenes del misterio de Nuestro Padre Jesús del Silencio en el Desprecio de Herodes, de la Hermandad de la Amargura, sobre el paso de metal repujado conocido popularmente como el Acorazado Potemkin. Tal actividad lo tuvo ocupado hasta su muerte en Sevilla el día veintidós de enero de 1923, a punto de cumplir los ochenta y uno.

\section{ASESORÍA ARTÍSTICA EN LA RESTAURACIÓN DEL MISTERIO DE LA SENTENCIA, EN 1880; Y EN LA REMODELACIÓN DEL AÑO 1898}

La primera intervención documentada de Virgilio Mattoni en la Hermandad de la Macarena es la que refiere a la asesoría artística de la restauración del misterio de la Sentencia tallado por Cristóbal Pérez, en 1681-84, incluida, según recientes estudios ${ }^{2}$, la imagen titular ${ }^{3}$. La intervención fue efectuada por el escultor

2 ÁLVAREZ CRUZ, Joaquín: “El misterio de la Sentencia”; en Esperanza Macarena. Historia, Arte, Hermandad; Sevilla, Editorial Tartessos, 2013, Vol. II, pp. 294 y sigs.

${ }^{3}$ SANCHO CORBACHO, Heliodoro: "Problemas de la imaginería procesional sevillana”; en Revista Calvario, Sevilla, 1947, SN, 39 y 40. Éste historiador del Arte rechazó con sólidos argumentos la identificación de la imagen con el contrato firmado por Felipe Morales Nieto en 1654. 
Emilio Pizarro de la $\mathrm{Cruz}^{4}$, en 1880. En esta fecha, el misterio se encontraba intacto, con la sola incidencia de la consolidación efectuada por el escultor Vicente Hernández Couquet ${ }^{5}$, en 1859.

Con posterioridad, el primer intento de remodelación del misterio de la Sentencia está datado en 1896, para lo que fue nombrada una comisión formada por Francisco de Mata y Muñoz, Alfredo Amores Domingo, Juan Manuel Rodríguez Ojeda, José María Holgado y Antonio Jalset ${ }^{6}$. La imposibilidad material de la ejecución retrasó unos años la intervención 7 , efectiva con Virgilio Mattoni como director artístico y, de nuevo, el escultor Emilio Pizarro como responsable de la ejecución ${ }^{8}$. El trabajo fue concertado con el mayordomo Alfredo Amores el día catorce de febrero de 1898, por siete mil reales; y el plazo de entrega fue estipulado el día treinta y uno de marzo del mismo año. La prensa confirmó los plazos $^{9}$. La ampliación de la canastilla, incluida en el mismo contrato, fue acordada con Hipólito Rossy y fijada en cinco mil reales ${ }^{10}$.

Francisco Almela Vinet fue uno de los primeros en comentarlo ${ }^{11}$, en 1889; aunque erró en la cronología de la túnica bordada, diseñada por Juan Manuel Rodríguez Ojeda, en 1888 y estrenada el año en el que redactó dicho texto. El primer estudio sobre esta remodelación fue efectuado por Jorge Bernales Balleste$\operatorname{ros}^{12}$, pasado casi un siglo. Lo primero que tuvo en cuenta fue el incumplimiento de lo estipulado en el contrato, la restauración de siete imágenes y la nueva talla

${ }^{4}$ BERMEJO Y CARBALLO, José: Glorias religiosas de Sevilla o Noticia históricodescriptiva de todas las cofradías de penitencia, sangre y luz, fundadas en esta ciudad; Sevilla, Imprenta y Librería del Salvador, 1882; edición facsímil en Mairena del Aljarafe, Sevilla, Extramuros Edición, 2008, pp. 191 y 192.

5 ÁLVAREZ CRUZ, Joaquín: "El misterio de la Sentencia”; op. cit., p. 294.

${ }^{6}$ Archivo de la Hermandad de la Macarena (AHM), Sección de la Esperanza 1.2.7. Libro de Acuerdos de Junta de Gobierno No 4, Acta del día 5-1-1896.

${ }^{7}$ AHM, Sección de la Esperanza 1.2.7. Libro de Acuerdos de Junta de Gobierno No ${ }^{\circ}$, Acta del día 26-1-1896.

${ }^{8}$ BERNALES BALLESTEROS, Jorge: "Retablos, esculturas, pinturas"; op. cit. p. 267. ÁLVAREZ ORTEGA, Santiago: "Evolución del misterio de la Sentencia"; en Esperanza Nuestra, $2^{\mathrm{a}}$ época $\mathrm{N}^{\circ} 115,2004$, p. 46. LUQUE TERUEL, Andrés: "Las imágenes titulares de la Hermandad de la Macarena"; en Esperanza Macarena. Historia, Arte, Hermandad, op. oit. Vol. II, p. 168.

9 ANÓNIMO: "Semana Santa"; en El Porvenir, siete de abril de 1898, p. 1.

${ }^{10}$ ROS GONZÁLEZ, Francisco S: "Los pasos de la Hermandad de la Macarena"; en AAVV: Esperanza Macarena. Historia, Arte, Hermandad, vol. III, op. cit., p. 353.

${ }^{11}$ ALMELA VINET, Francisco: Semana Santa en Sevilla, Historia y descripción de las cofradias que hacen estación durante la misma a la Santa Iglesia Catedral; Sevilla, 1899; Córdoba, 2003, pp. 39 y 40; edición facsímil en Mairena del Aljarafe, Sevilla, 2009, Cofradía de San Gil, pp. 5 y 6.

12 BERNALES BALLESTEROS, Jorge: "Retablos, esculturas y pinturas"; op. cit., pp. 267 y 268 . 
de otras siete, lo que haría un total de catorce en el nuevo misterio reformado y ampliado $^{13}$. Según dedujo, la causa para ese cambio de planes y la reducción de la reforma prevista en contrato pudo estar en los fuertes gastos de la época. Por ello, expuso que el escultor se limitó a realizar nuevos cuerpos; a suavizar y anular el aspecto caricaturesco de las cabezas de las imágenes de Cristóbal Pérez, mantenido antes en las restauraciones de Vicente Hernández Couquet a mediados de siglo y él mismo en 1880; y a cambiar las ropas de tradición judía por otras de origen romano. Santiago Álvarez Ortega aportó un dato complementario, la compra de varias imágenes a la Hermandad del Valle, en 1898, por una cantidad de mil reales, lo que contrasta con los cinco mil quinientos reales estipulados para la remodelación y ampliación prevista ${ }^{14}$.

Joaquín Álvarez Cruz, autor de un riguroso estudio documental y artístico, dividido en los aspectos históricos, iconográficos y plásticos, con sus consiguientes reflexiones y conclusiones ${ }^{15}$, publicó el contrato aludido ${ }^{16}$, iniciativa que desveló las condiciones estipuladas con Emilio Pizarro respecto de la composición del misterio ${ }^{17}$. Una vez identificadas las imágenes eliminadas del misterio original de Cristóbal Pérez, muy llamativa la de Poncio Pilato por su carácter anacrónico con barba y turbante, más difíciles de identificar las del sanedrita sentado y uno de los criados, Joaquín Álvarez Cruz precisó las que estimó retalladas por Emilio Pizarro ${ }^{18}$ : entre los originales barrocos, el otro criado y los sanedritas sentados, y con éstas las recién adquiridas a la Hermandad el Valle ${ }^{19}$, los dos sayones y la María, para lo que se apoyó en la documentación gráfica aportada por Jorge Valle ${ }^{20}$. Según estimó, la retalla de Emilio Pizarro debió ser muy intensa, pues supuso la transformación de los dos sayones hebreos recién adquiridos en dos nuevos soldados romanos y de la imagen femenina en la de Poncio Pilato con caracteres latinos. Por último, propuso como obra de nueva talla debida a este escultor la del

${ }^{13}$ BERNALES BALLESTEROS, Jorge: "Retablos, esculturas y pinturas"; en Esperanza Macarena en el XXV Aniversario de su Coronación Canónica, op. cit., p. 267. ÁLVAREZ CRUZ, Joaquín: "El misterio de la Sentencia”, op. cit., vol. II, p. 270.

14 ÁlVAREZ ORTEGA, Santiago: "Evolución del misterio de la Sentencia", op. cit., pp. 46 y 47.

${ }^{15}$ ÁLVAREZ CRUZ, Joaquín: "El misterio de la Sentencia”, op. cit., vol. II, pp. 260301.

${ }^{16}$ Ibídem, p. 271.

${ }^{17}$ AHM, Libro de Mayordomía, legajo 12. ÁLVAREZ CRUZ, Joaquín: "El misterio de la Sentencia", op. cit., vol. II, p. 271.

18 ÁLVAREZ CRUZ, Joaquín: "El misterio de la Sentencia"; op. cit. vol. II, P. 295.

${ }^{19}$ AHM, Libro de Mayordomía, legajo 12. Álvarez Cruz, Joaquín: "El misterio de la Sentencia”, op. cit., vol. II, p. 270.

${ }^{20}$ VALLE, Jorge: "Los pasos e imágenes desaparecidos en Sevilla. Capítulo V (Hermandad del Valle)"; en cofrades.pasionensevilla. 
Sanedrita acusador situado en pies delante de los sillones laterales, que sustituyó al sedente suprimido.

Según pensó ${ }^{21}$, la incorporación de estas imágenes y la reforma de las de Cristóbal Pérez por parte de Emilio Pizarro permitieron a la Hermandad la reducción de los costes y la actualización del misterio, con lo que apoyó la propuesta de Jorge Bernales Ballesteros con la nueva referencia aportada por Santiago Álvarez $^{22}$. La conclusión de Joaquín Álvarez Cruz fue reveladora, estimó que la influencia de Virgilio Mattoni fue determinante para que Emilio Pizarro adecuase el misterio de la Sentencia a los principios realistas desarrollados en la pintura de historia sevillana desde Eduardo Cano y, sobre todo, a los dictados historicistas del cuadro titulado Ecce Homo, del pintor húngaro Mihály Munkácsy ${ }^{23}$, fechado en 1891. Esto se tradujo en un interesante cambio iconológico apoyado en la expresión de las figuras ${ }^{24}$.

Por lo tanto ${ }^{25}$, es necesaria una nueva lectura formal de las imágenes bien identificadas en las fotografías fechadas con seguridad, tanto para establecer con la mayor precisión posible el aprovechamiento de las procedentes de la Hermandad del Valle, como para identificar las que pudo realizar Emilio Pizarro. Esas fotografías muestran la inversión de las posturas de los dos soldados romanos situados en la delantera del paso, debida al cambio de posición entre ellos, lo que explica los distintos movimientos (Figura 3). Aislándolos visualmente y colocándolos virtualmente en el lado opuesto vemos que coinciden con los antiguos. Debido al giro interior, las fotografías no muestran las cabezas completas; sin embargo, los rasgos de los rostros en las que ofrecen mayores porciones de volúmenes, confirman tal identidad y la suavización de los rasgos, en consonancia con las demás imágenes de Cristóbal Pérez retalladas por Emilio Pizarro para adaptarlas a los gustos realistas e historicistas introducidos por Virgilio Mattoni.

De los tres sanedritas sedentes, dos son seguros originales de Cristóbal Pérez reformados por Emilio Pizarro (Figuras 1 y 2); el tercero no se aprecia bien en ninguna fotografía, aunque su silueta parece muy aproximada a la original; y el cuarto fue sustituido por el nuevo en pies y en actitud de acusar a Cristo. Éste puede identificarse perfectamente en la antigua y conocida fotografía del misterio de la calle de la Amargura (Figura 2), justo detrás de la cruz de Nuestro Padre

${ }^{21}$ ÁLVAREZ CRUZ, Joaquín: "El misterio de la Sentencia”, op. cit., vol. II, pp. 271 y 272 .

${ }^{22}$ Ibídem, p. 270.

${ }^{23}$ Ibid., p. 295.

${ }^{24}$ Ibid., p. 288.

${ }^{25} \mathrm{El}$ incumplimiento de las condiciones y los objetivos establecidos en un contrato es muy frecuente en el Arte Español Moderno y Contemporáneo, por lo que es imprescindible tener en cuenta la relatividad de éstos y la necesidad de los análisis formales que permitan dilucidar la realidad. 
Jesús Nazareno, en el centro del grupo que lo sigue. Los rasgos físicos coinciden de pleno y varía la actitud, circunstancia lógica debida a la transformación debida a Emilio Pizarro para adaptarlo a su nueva función y proporciones (Figura 3). No fue, pues, una imagen de nueva talla, sino la adaptación de una imagen antigua recién adquirida, como parece probable para abaratar los costes de la ampliación recogida en el contrato.

Sobre el segundo sayón procedente de la Hermandad del Valle no tenemos ninguna noticia, $\mathrm{y}$, aunque poco probable, la única opción a tener en cuenta es la hipotética incorporación en lugar del tercer sanedrita sedente de Cristóbal Pérez. Si hubiese sido así, Virgilio Mattoni y Emilio Pizarro lo habrían transformado de modo radical, adaptándolo a una nueva postura, con las dificultades que esto conlleva por la realidad de los principios orgánicos de la anatomía y la lógica falta de coordinación con los nuevos movimientos (Figura 3). Las posturas solemnes de los tres sanedritas sedentes, distintas a las gesticulantes de época barroca, coinciden con la del Papa León XIII pintado por Virgilio Mattoni, conservado en el Seminario de Sevilla. La aportación iconográfica, formal y estilística del pintor fue determinante para la intervención de Emilio Pizarro, un escultor muy activo en aquella época; mas un tanto dependiente en cuestiones compositivas y limitado en carácter creativo.

Más probable es la remodelación y adaptación de la imagen femenina para convertirla en la nueva de Poncio Pilato, propuesta por Joaquín Álvarez. Ninguna fotografía antigua muestra la incorporación de Claudia Prócula, como propuso Santiago Álvarez, hasta el misterio de Castillo Lastrucci, en 1929. Las únicas posibilidades son esta transformación o su descarte una vez adquirida. Lo primero es posible, pues el carácter latino, esto es, con el rostro afeitado y el pelo corto con flequillo de tipo iulio-claudio propio de los tiempos del emperador Tiberio, y la condición gesticulante, coinciden con una de las imágenes de la fotografía de referencia y reflejan cierta blandura y aire femenino (Figura. 3). La postura es análoga a la de Dios Padre en la Santísima Trinidad pintada por Virgilio Mattoni, conservada en el altar de la Virgen de Belén de la Catedral de Sevilla, cerca de 1893; y a la del mismo pintor conservada en la Iglesia de San Andrés, éste de gran formato y firmado y fechado en 1903. La ascendencia de Virgilio Mattoni fue determinante en los dos casos, tanto si se tratase de la imagen procedente de la Hermandad del Valle reformada por Emilio Pizarro, tal es muy probable, como si fuese obra de nueva factura de éste último.

De los dos criados de la primera fotografía (Figura 1), cuyo origen no es claro y no concuerdan con los originales barrocos de Cristóbal Pérez, por lo que no sabemos si fueron añadidos por Vicente Hernández Couquet, en 1859, o por distinta iniciativa en otra fecha indeterminada del siglo XIX, sólo queda uno en las fotografías posteriores a 1898 (Figura 3), el que iba a la derecha de Poncio Pilato. Virgilio Mattoni y Emilio Pizarro mantuvieron con esta imagen la escala decreciente de ascendencia medieval y aprovecharon el aspecto latino que se observa en 
el primer documento gráfico, previo a la reforma que nos ocupa. La transformación fue mínima, pues la imagen, de época por determinar, anticipaba rasgos latinos; no obstante, éstos eran ajenos al rigor historicista de Virgilio Mattoni y la pintura del último cuarto del siglo XIX, circunstancia que se aprecia mucho mejor en el criado desechado (Figura 1), con pelo y peinado de época romántica anterior a 1860, ajeno a las modas latinas de tiempos de Tiberio.

En definitiva, si el Señor de la Sentencia permaneció intacto (Figura 4), como puede asegurarse, los dos soldados romanos y dos sanedritas sentados son los originales de Cristóbal Pérez; el tercero de estos cuatro también puede ser el original barroco o uno de los dos sayones adquiridos a la Hermandad del Valle, convenientemente adaptado; el cuarto está identificado como el otro de esos dos sayones; la imagen de Poncio Pilato pudiera ser la María con idéntica procedencia, adaptada y retallada; y el niño sirviente procede al menos de época de Vicente Hernández Couquet. Puede afirmarse con rigor que Emilio Pizarro no talló ninguna figura, pese a lo estipulado en el contrato. Su trabajo consistió en la adaptación de las imágenes a las nuevas proporciones que las igualaron con la imagen del Señor de la Sentencia, antes de mayor altura y envergadura, despojándolas de las facciones caricaturescas y dotándolas con ropas, actitudes y rasgos realistas, acordes con el pasaje histórico que representan. La dirección y supervisión del pintor Virgilio Mattoni fue decisiva, tanto en la impronta creativa e interés por la veracidad histórica que se manifiesta en los nuevos detalles compositivos, como en las pautas de los diálogos y los rasgos físicos, cualquiera que fuese su procedencia. La actualización en concordancia con los principios de la pintura de historia rompió con los criterios barrocos que mantenían el principio medieval de identificación de lo bueno con la belleza y lo malo con la fealdad grotesca; e igualmente, con la interpretación anacrónica de los hebreos antiguos según las modas palestinas que los escultores barrocos aplicaron en el siglo XVII. Esto supuso un claro giro en la tradición de las representaciones pasionistas de la Semana Santa sevillana, desde este momento tendente a las interpretaciones historicistas que lo proyectaron en las élites culturales de finales del siglo XIX.

\section{ASESORÍA ARTÍSTICA EN LA RESTAURACIÓN DE LA VIRGEN DE LA ESPERANZA (MACARENA), EN 1881}

Las fotografías de la Virgen de la Esperanza (Macarena) en el último cuarto del siglo XIX permiten analizar y estudiar con rigor el estado de la imagen antes y después de la intervención asesorada por Virgilio Mattoni, ejecutada por el escultor Emilio Pizarro de la Cruz en 1881, el mismo año que restauró el misterio de las Siete Palabras. Esas fotografías pueden fecharse con exactitud por las soluciones de los vestidores, bien conocidas; por la cronología de las prendas bordadas, documentadas y conservadas; y por las coronas que porta como símbolo de realeza, propias también de momentos concretos. Tal variedad de combinaciones 
de elementos identificados y documentados permiten acotar los márgenes con cierta exactitud.

Las fotografías anteriores a la intervención permiten el análisis formal de la imagen barroca en un estado bastante aproximado al original de la segunda mitad del siglo XVII (Figuras 5 y 6). Sólo una de ellas ofrece dudas en la identificación de la imagen, tanto por la claridad de las diferencias en la zona de los ojos, intervenidos después, como por la falta de identificación de los elementos del ajuar (Figura 5); sin embargo, la comparación digital de los volúmenes con las otras fotografías antiguas y las actuales ofrece una gran similitud, motivo que induce a considerarla válida. La posición frontal de la imagen está marcada por una leve inclinación hacia delante, fundamental para la interpretación de los movimientos anatómicos, conseguidos mediante formulas realistas avanzadas; mas con criterios orgánicos derivados del naturalismo, como fue habitual en Pedro Roldán. La suave y mínima caída de los párpados completa tal disposición, de modo análogo a la Virgen del Descendimiento del retablo de los Vizcaínos de Pedro Roldán, en 1666; y a la Virgen de la Piedad de la Hermandad de la Sagrada Mortaja, también anónima y, como en este caso, titular de una corporación cuyo misterio fue tallado por Cristóbal Pérez en el margen cronológico indicado. En ninguna de esas fotografías se aprecian lágrimas sobre el rostro de la Virgen de la Esperanza.

El cuello, muy bien simplificado, le proporciona una base firme e idónea (Figuras 8 y 9). El desplazamiento alternativo y asimétrico de los ejes y los elementos faciales asociados originan una configuración muy singular. La frente, amplia, despejada, contundente, suaviza la fuerte contracción de las cejas, proporcionando una fuga muy adecuada y bellísima; adquiere una cierta autonomía; y propicia la localización de una serie de efectos realistas en el eje facial. La nariz, eje vertical determinante, está ligeramente desviada hacia la derecha y, en consecuencia, abierta con suavidad proporcional en el lado contrario, con un espacio mayor para ese ojo. La alineación de éstos y la boca pierden el paralelismo debido a la ligera caída exterior del ojo derecho, que ocupa así el espacio liberado por el desplazamiento de la nariz y la inclinación inversa de la boca. Esto genera un nuevo efecto, pues mientras la comisura derecha de los labios tiende a subir, la izquierda, como es lógico, tiene que bajar. Esto tiene varias consecuencias, por una parte la animación de la mirada, remarcada por la distinta extensión de las cejas y los espacios resultantes, que aporta una extraordinaria carga de temperamento y fuerza vital, traducidos en sensación de vida y una extrema personalidad; y, por otra, una característica sensación de risa y llanto simultáneo.

Las manos presentan una singular combinación en el movimiento de los dedos, en ambas el medio o corazón y el anular se agrupan y desplazan hacia el interior, sin perder la extensión; el índice se desplaza hacia fuera, en sentido contrario a los dos anteriores; el meñique mantiene la posición respecto de la verticalidad natural de la palma de la mano; y el pulgar gira hacia el interior con un sentido 
envolvente contrario a la dirección centrífuga del anterior. La disposición genera un movimiento muy acusado, que no pierde la condición expresiva corporal. La simbiosis de principios es perfecta, tanto como la de las relaciones plásticas en el conjunto y los detalles de la cara.

El resultado de tales combinaciones puede considerarse único por el alcance de su potencia expresiva y es incomparable por la inmensa personalidad y la incontestable belleza del resultado. Las decisiones técnicas del afortunado escultor anónimo fueron fundamentales para la definitiva consagración de tanta belleza. Incluso en las fotografías más antiguas se aprecia la talla suelta y movida, con cortes firmes y decididos, a veces muy contundentes, aplicados siempre con un sentido estructural prioritario; otras con golpes de gubia superficiales, mínimos, apenas perceptibles y muy sutiles, capaces de velar las superficies y responsables de la definición de los detalles anatómicos. Las transiciones, muy brillantes, modulan los cambios y simulan la naturaleza de los cortes.

El equilibrio es propio de la escultura avanzada de la segunda mitad del siglo XVII, detectado, con ese sentido e intensidad, desde las primeras obras de Pedro Roldán a mediados de siglo. Dicho fundamento permite atribuirle a este escultor la autoría del modelo de la Virgen de la Esperanza, tanto en lo relativo a las características iconográficas como a las propiedades de la configuración, y, con más reservas, las características específicas de la talla, coincidente con las de sus primeras obras. Un grafismo concreto, la peculiar caída de los párpados, la relaciona tanto con el citado maestro como con el anónimo autor de la Virgen de la Piedad de la Hermandad de la Sagrada Mortaja, que, según lo expuesto, pudiera ser Cristóbal Pérez, autor también del misterio y muy probablemente del Señor de la Sentencia.

Las fotografías fechadas después de la intervención asesorada por Virgilio Mattoni muestran una menor inclinación del busto (Figuras. 7, 8 y 9), debida quizás a una lógica sustitución del candelero. También se aprecia en ellas una mayor apertura de los párpados, que puede ser debida al ligero cambio de posición mediante una inclinación distinta de dicho candelero o por la acción de una cuña en el antiguo, en los dos casos elevando la cara, o, incluso, por la colocación de los actuales ojos de cristal, pintados por dentro. Las dos primeras opciones se desmienten con la corrección de la verticalidad que ya se observa en otras fotografías anteriores a esta intervención (Figuras 5 y 6), por lo que no sería debida a Virgilio Mattoni, cuestión que se complica con la aparente recuperación del ángulo original en otras fotografías de la Virgen de la Esperanza en el paso (Figura 7), de las que podría deducirse que tal corrección era efímera y estaba supeditada a los distintos montajes, antes y después de esta intervención. Sí es cierto que a finales de siglo ya aparece en todas las fotografías en la posición actual, por lo que podría deducirse una fijación posterior, que sería la responsable de la modificación del grafismo que la relacionaba de modo directo con la Virgen de la Piedad 
de la Hermandad de la Sagrada Mortaja y, por extensión, con Cristóbal Pérez; y del consiguiente y leve cambio de la expresión.

Las mismas fotografías muestran que la talla de la Virgen de la Esperanza (Macarena) permanece prácticamente intacta, por lo que la modificación es reversible y sólo consiste en devolverle a la imagen la inclinación apropiada. En este punto hay que advertir que todas las dolorosas sevillanas del siglo XVII presentan en la actualidad idéntica corrección, con la consiguiente merma visual de los valores plásticos originales. Ésta, capaz de minimizar el posible vínculo con Cristóbal Pérez; sin embargo, no anula las características técnicas y formales que remiten a la creatividad y el estilo de Pedro Roldán. Sólo la intensa influencia de éste sobre todos los escultores de su tiempo dejan el asunto de la autoría sin resolver.

La tercera opción indicada, la mayor apertura de los párpados debida a la colocación de los ojos de cristal, es muy posible e iría asociada a la recuperación o nueva colocación de lágrimas del mismo material, como ya vimos inexistentes en las fotografías más antiguas. Supuso una segunda e igualmente leve modificación. Con la primera decisión, muy de moda en el siglo XIX, Virgilio Mattoni y Emilio Pizarro aportaron un nuevo matiz al original barroco relacionado con Pedro Roldán, y lo hicieron sin modificar ninguna de las características fundamentales de la talla, perceptibles en los análisis formales actuales ${ }^{26}$. Igualmente, la segunda decisión fue fundamental para la recuperación del discurso iconográfico de la dolorosa que rompe a llorar o mantiene un llanto nervioso, muy humano, tan intenso y dramático como la belleza que la encumbra. Las pestañas son elementos postizos que aumentan el realismo y las características y la belleza femenina; aunque las de época de Virgilio Mattoni no han llegado a nuestros días.

En consecuencia, Virgilio Mattoni veló por la conservación de las características originales de la composición y la talla, reduciendo a lo mínimo el posible impacto de la colocación de ojos de cristal, en una época en la que la mayoría de intervenciones sobre imágenes antiguas suponía la profunda renovación de la misma, por lo general con técnicas de retalla que las modificaban para siempre anulando las cualidades originales; otras veces con remodelados que ocultaron tales originales, haciendo muy difícil su posterior recuperación por la identificación de la devoción popular. Su preocupación por la identidad del patrimonio heredado fue fundamental y gracias a él la Virgen de la Esperanza ha llegado a nuestros días en un estado muy aproximado a como fue concebida y con la posibilidad de efectuar los estudios formales que permiten dilucidar los pormenores de su autoría.

${ }^{26}$ LUQUE TERUEL, Andrés: "Las imágenes titulares de la Hermandad de la Macarena"; en Esperanza Macarena. Historia, Arte, Hermandad, op. cit., pp. 162-168. 


\section{UNA PINTURA INÉDITA: LA VIRGEN DE LA ESPERANZA SALIENDO DE LA IGLESIA DE SAN GIL, EN 1896}

La reciente identificación en el domicilio de una familia macarena de un lienzo inédito pintado por Virgilio Mattoni, titulado La Virgen de la Esperanza saliendo de la Iglesia de San Gil (Figura 10), permite ampliar la relación del pintor con la corporación y su ámbito inmediato en los años finales del siglo XIX.

La pintura está firmada, fechada y dedicada: Al señor Don C. Segovia su afectísimo $V$. Mattoni, 1896. Esta circunstancia aumenta su interés, y, del mismo modo, el hecho de conservarse en un domicilio muy próximo al Arco de la Macarena, como propiedad de una familia que ya vivía en el barrio en aquella época y aún muestra un profundo apego a la Hermandad y a la Virgen de la Esperanza. Virgilio Mattoni recibió el encargo o decidió hacer un regalo muy especial a un macareno de aquel contexto, en el que significa y del que la pintura nos ofrece importantes testimonios, además de su indudable calidad artística.

Dos factores destacan a primera vista, la técnica grisalla, con un austero y brillante sentido monocromo; y la manifiesta modernidad de la limitación de la composición al centro del soporte de lino que, descubierto y visto en un amplio perímetro, forma parte de la composición, a la que enmarca debido al valor de la contrasilueta formada por los perfiles nítidos, rectos y geométricos, del espacio perimetral liberado. La composición es compleja debido a los distintos planos en perspectiva, sobre todo, los que corresponden a un sepulcro abierto en la línea de tierra y, en contraste debido al ángulo virtual, el motivo central de la Virgen de la Esperanza en su paso de palio en la embocadura de la puerta ojival de la Iglesia de San Gil. De ese sepulcro salen un Senatus y varias cruces, símbolos de la pasión y muerte de Cristo, tema central de la primitiva advocación de la Virgen de la Esperanza, entendida como la doble expectación de María ante el nacimiento de Cristo y la entrega de su cuerpo para la redención de los pecados, según consta en las Reglas fundacionales del año 1595.

La alegoría de la pintura de Virgilio Mattoni representa la vinculación de la Virgen de la Esperanza con el cuerpo de Cristo y la penitencia. La nueva lectura, en clave simbólica, asume los aspectos inciertos y aun tenebrosos propios de la mentalidad romántica heredada en los ambientes cultos de la ciudad, sensibles también al nuevo realismo, y da sentido tanto a la propia advocación de la Virgen de la Esperanza en su acepción original, como a la procesión de penitencia en la Madrugada del Viernes Santo, que representa. Los tres nazarenos superpuestos en el primer plano, en el lado izquierdo del lienzo, visten las túnicas con capas circulares proyectadas por Juan Manuel Rodríguez Ojeda, en 1888. Ese diseño, novedoso y llamativo, supuso una afortunada aportación a la celebración pasionista, por lo que sería un motivo atractivo para la composición pictórica. El primero porta la bandera verde de la corporación, abierta y volada en señal de luto propio del Viernes Santo, circunstancia que le proporcionó a Virgilio Mattoni 
un recurso plástico adecuado como pantalla capaz de generar una falsa perspectiva por superposición en todo el frente superior, que supera invadiendo la parte perimetral liberada de lino. Su mirada hacia la derecha, al exterior del cuadro y arriba, aporta un nuevo matiz en relación con el canto de una supuesta saeta, y desplaza el capirote hacia el extremo izquierdo del soporte, ampliando las relaciones plásticas. El segundo se deja ver en el margen izquierdo, mientras se ajusta el antifaz, mirando hacia el exterior, como buscando a alguien entre el público. Su capirote se desplaza hacia detrás, esto es, hacia el interior ocupado por el paso de la Virgen de la Esperanza, cruzándose con el capirote del primero. La diagonal exterior de la vela encendida refuerza la dirección de su mirada. Del tercero, detrás y casi oculto, sólo se ve el vértice del capirote por la parte interior.

La sugestiva superposición y el movimiento sinuoso proporcionado por los respectivos desplazamientos de los tres nazarenos generan una falsa perspectiva envolvente, acotada por la superación de los límites de la bandera volada en la parte superior, que determina el espacio del centro de la composición, justo delante del paso de la Virgen de la Esperanza, ocupado en un nivel intermedio por un sacerdote cuya mirada coincide con la del primer nazareno, con el que concuerda la actitud admirativa reforzada por la mano sobre la cabeza; en segundo plano por una mujer arrodillada delante del paso y con los brazos abiertos, en señal de ofrecimiento y aclamación; en tercero, por un monaguillo con incensario desplazado delante del costero derecho del paso; y, en cuarto y último lugar, por un nazareno cerrando el margen entre dicho costero y la puerta ojival. La excelente concepción espacial es debida a una magistral interpretación de la luz, asociada tanto a los movimientos de las figuras como a las manchas sueltas y las veladuras que determinan las sensaciones aéreas en dos zonas concretas, la diagonal ascendente proporcionada por el humo del incienso y la masa luminosa de la candelería del paso de palio. El alto grado de abstracción de esos elementos sirve a un propósito de naturaleza muy distinta, el realismo conseguido con la sugerencia de factores intangibles imprescindibles.

El paso de la Virgen de la Esperanza ya está en la calle. La noche estrellada lo indica y abre el horizonte en la parte superior. La representación, un tanto abocetada, es, pese a ello, muy precisa. Los bordados del palio negro diseñado por Juan Manuel Rodríguez Ojeda, en 1889, realizados en el taller dirigido por su hermana Josefa Rodríguez Ojeda, en 1899-90, se identifican por el corte de las caídas, el movimiento de las masas vegetales y la heráldica del frontal. Los varales son los metálicos lisos documentados en el año 1890. El paso no tiene respiraderos, sólo una moldura, licencia artística para descargar visualmente la parte inferior, según se deduce de la comparación con las numerosas fotografías que muestran los respiraderos metálicos y los faldones diseñados por Juan Manuel Rodríguez Ojeda y bordados por Eloisa Rivera, en 1879-84. La Virgen de la Esperanza está vestida por aquél, el tocado es el de tres picos propio de la época, el manto no se distingue, mas debería ser el que él mismo proyectó y bordó la segunda, en 1879-84; la 
saya es lisa y lleva un cíngulo centrado al modo clásico; luce la corona que aparece en las fotografías fechadas entre 1879 y 1890; y lleva símbolos barrocos como el puñal clavado en el pecho, suprimido por Juan Manuel Rodríguez Ojeda en 1913, y la luna menguante a sus pies. La candelería baja y muy abierta permite apreciar todos esos detalles. Virgilio Mattoni dejó un testimonio muy preciso del paso y de cómo iba vestida la Virgen de la Esperanza en 1896.

Otro aspecto a tener en cuenta es la descripción de la portada ojival de la Iglesia de San Gil antes de la mutilación de principios del siglo XX, así como su relación con la fachada, de la que sobresale la parte superior de la torre. Recordemos que Virgilio Mattoni era miembro de la Comisión Nacional de Monumentos, y su sólido compromiso con los bienes patrimoniales. Esto le proporciona un enorme interés a la pintura, pues es previsible un gran rigor en la representación, que adquiere aún más valor con la falta de documentos gráficos que permitan comprobar cómo era. Estaba formada por cinco arquivoltas ojivales sobre baquetones, y la clave a cierta distancia del tejaroz sobre ménsulas indica la cronología del siglo XIV, correspondiente a la ampliación de la Iglesia en tiempos de Pedro I. No se ven los capiteles de los baquetones ni los motivos esculpidos en las ménsulas; sin embargo, no son necesarios para la datación en la época de dicha ampliación.

Por último, un elemento superpuesto en la parte superior derecha del soporte simula la fijación de la escena sobre la superficie de lino descubierta. Es el antiguo escudo corporativo, incluido en una cartela barroca que recuerda las sevillanas de la primera mitad del siglo XVII. Está formado por un ancla de la Esperanza cruzado con el báculo de San Gil y la mitra de éste superpuesta, todo orlado por el Santo Rosario ajustado al perfil interno circular. La estructura adquiere un nuevo perfil casi cartilaginoso con el apoyo sobre acantos abiertos y curvados sobre su eje, que, a su vez, sostienen roleos costillados verticales, de los que parten acantos similares a los anteriores, éstos flanqueando el escudo de María coronado que lo remata y preside. Ese escudo tiene una doble función, como casi todos los elementos de la composición. El efecto de fijación le proporciona identidad desde un punto de vista plástico, evitando el distanciamiento entre el novedoso fondo textil visto y la representación, lo que hace por alusión directa que ésta superficie forme parte de la configuración, como un elemento más con un propósito concreto y una incidencia precisa. Tiene idéntico protagonismo en la segunda función, simbólica, pues la heráldica es el emblema de la corporación que anuncia.

En conclusión, la pintura de Virgilio Mattoni ofrece otros matices de su personalidad artística, con una interesante inclinación a las novedades plásticas, sin renunciar por ello ni a su formación postromántica ni al entonces novedoso interés realista de la interpretación. La exhaustiva planificación de la composición y el magisterio en la ejecución de las sensaciones aéreas con recursos avanzados, avalan la categoría intelectiva de la configuración. La alusión al contenido teológico de la advocación original de la Virgen de la Esperanza, en relación con el Santo Cristo y, en sustitución de éste, la alegoría de la penitencia en torno a la 
pasión y muerte, le proporcionan una profundidad que trasciende tales categorías y, por supuesto, el simple hecho descriptico de una procesión. Ésta se manifiesta en un nivel alternativo como un documento excepcional del paso y el ajuar de la Virgen de la Esperanza, de la faceta creativa del vestidor y de la realidad física de un importante monumento medieval perdido.

Fecha de recepción: 12 de septiembre de 2014

Fecha de aceptación: 28 de noviembre de 2014

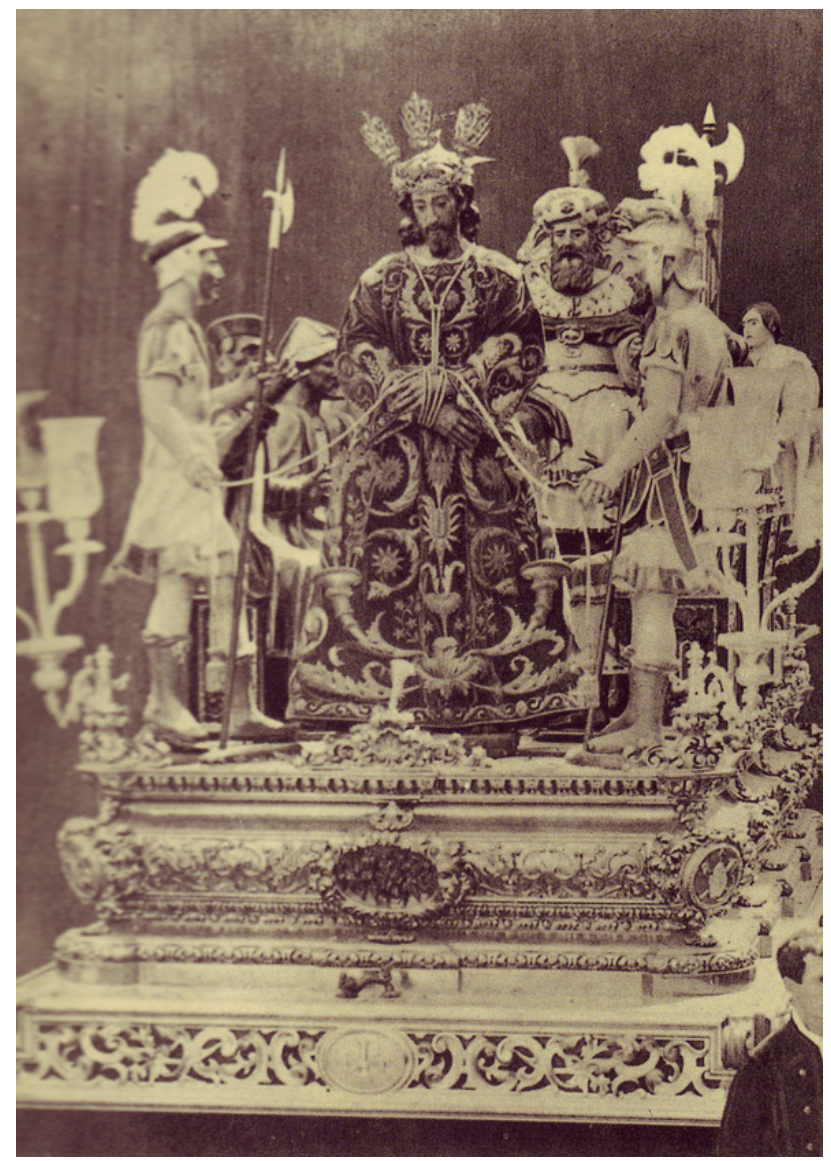

Figura 1. Misterio de la Sentencia antes de la restauración supervisada por Virgilio Mattoni en 1880. 


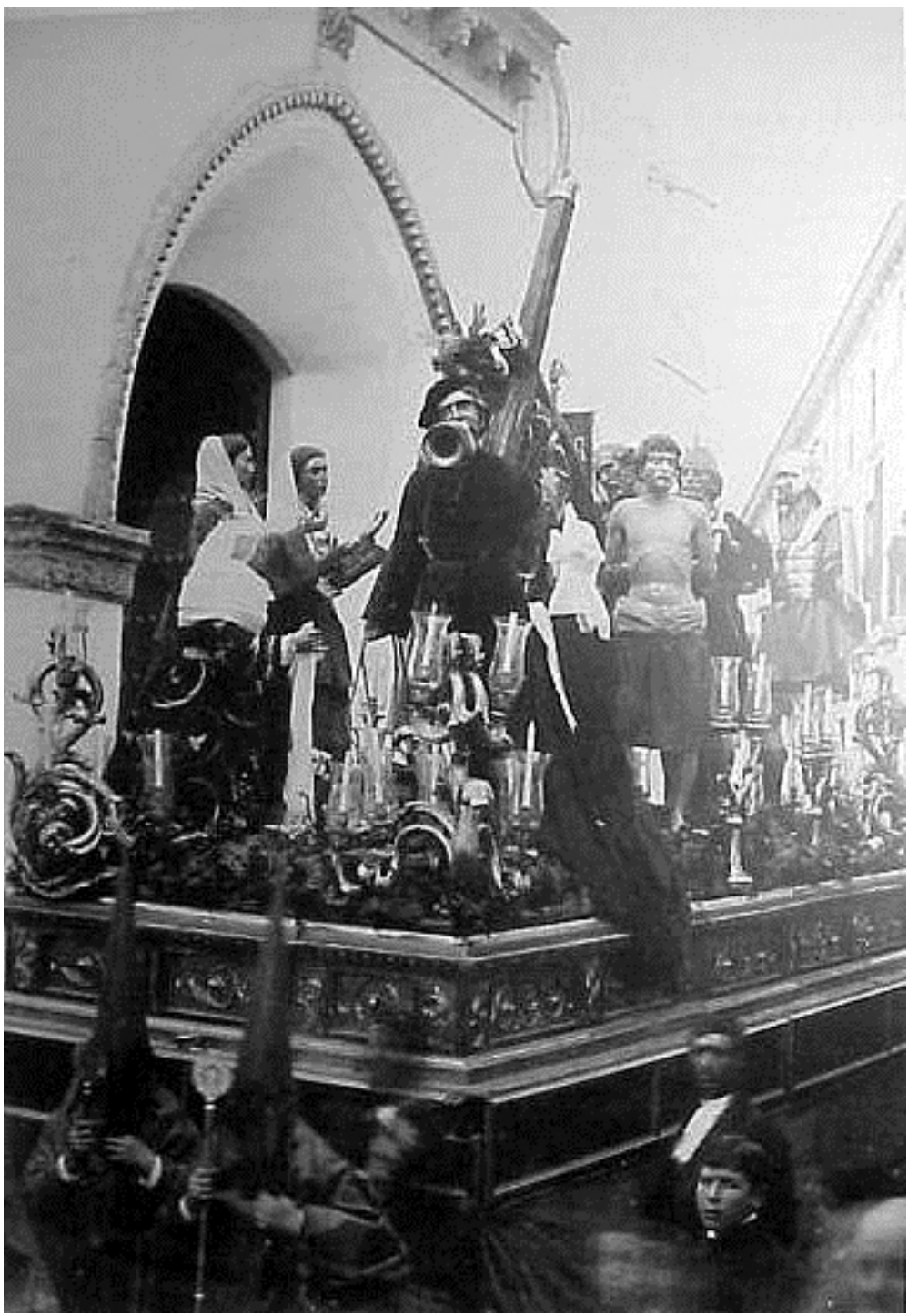

Figura 2. Misterio de Jesús con la cruz al hombro en la calle de la Amargura, de la Hermandad del Valle. Aún se aprecian las imágenes compradas por la Hermandad de la Macarena en 1898. 


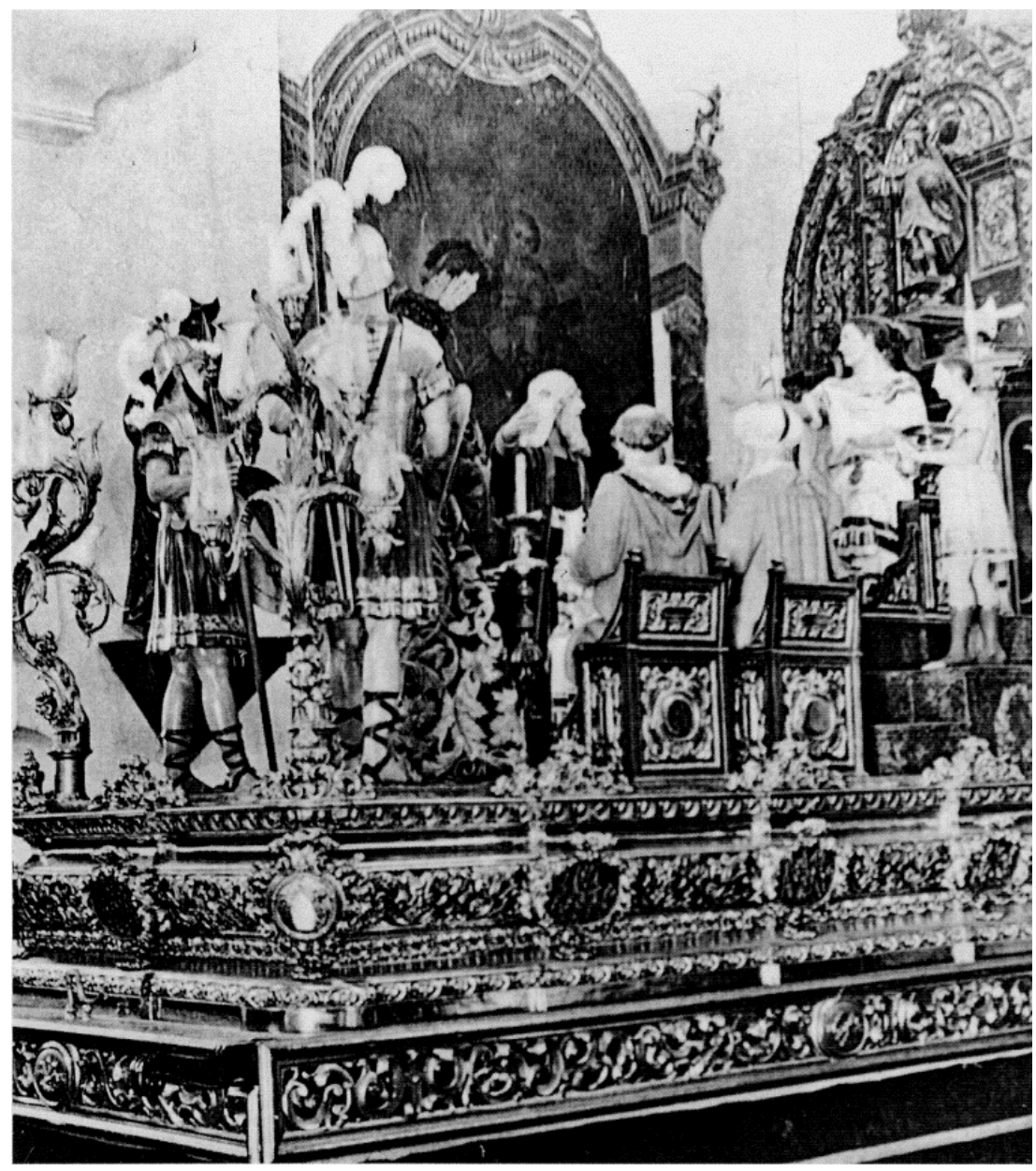

Figura 3. Misterio de la Sentencia reformado por Emilio Pizarro con la supervisión de Virgilio Mattoni en 1898. 


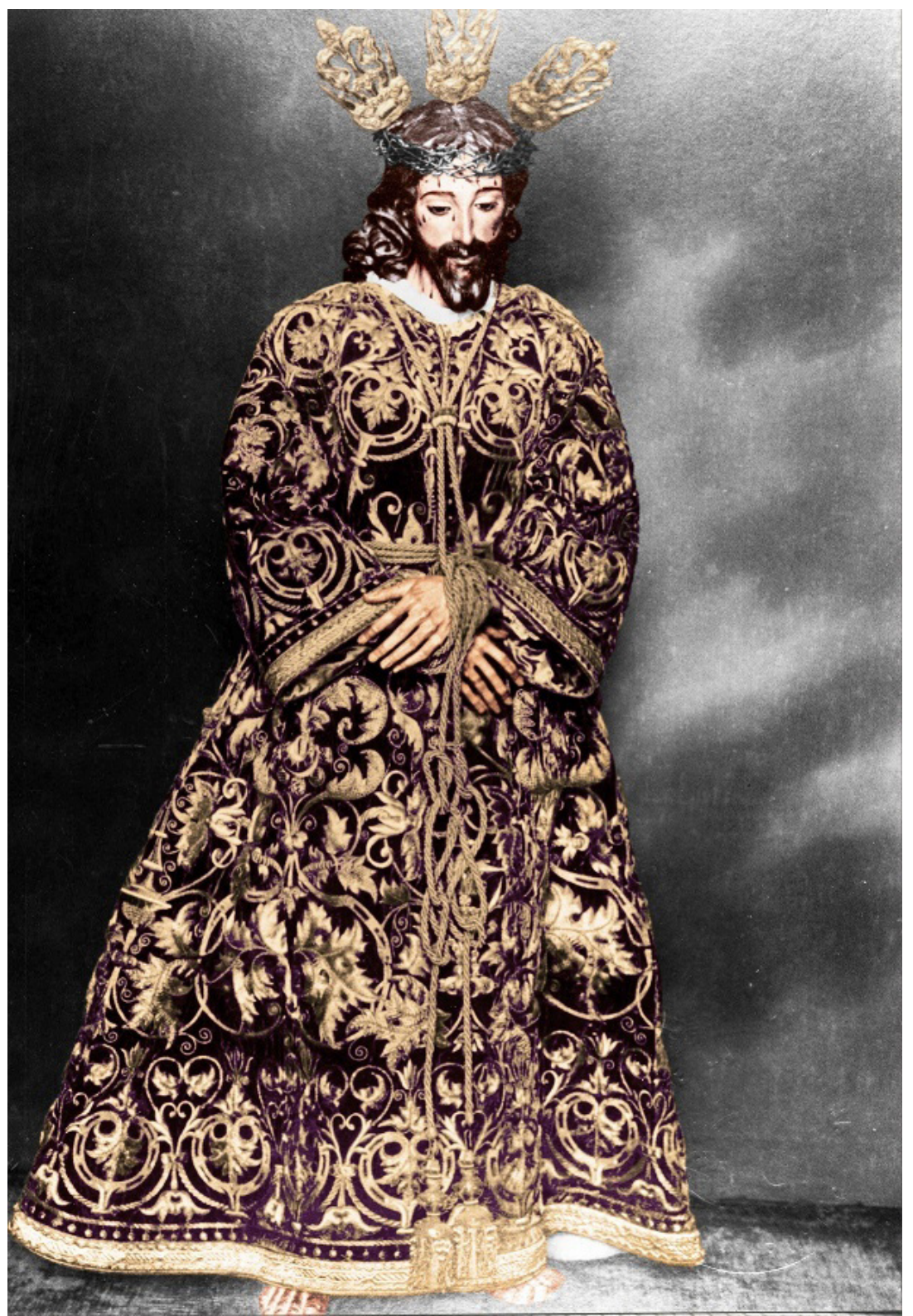

Figura 4. Imagen del Señor de la Sentencia, posible obra de Cristóbal Pérez en 1681, en una fotografía posterior a 1910. Virgilio Mattoni propició la conservación de los caracteres originales de la talla barroca. 


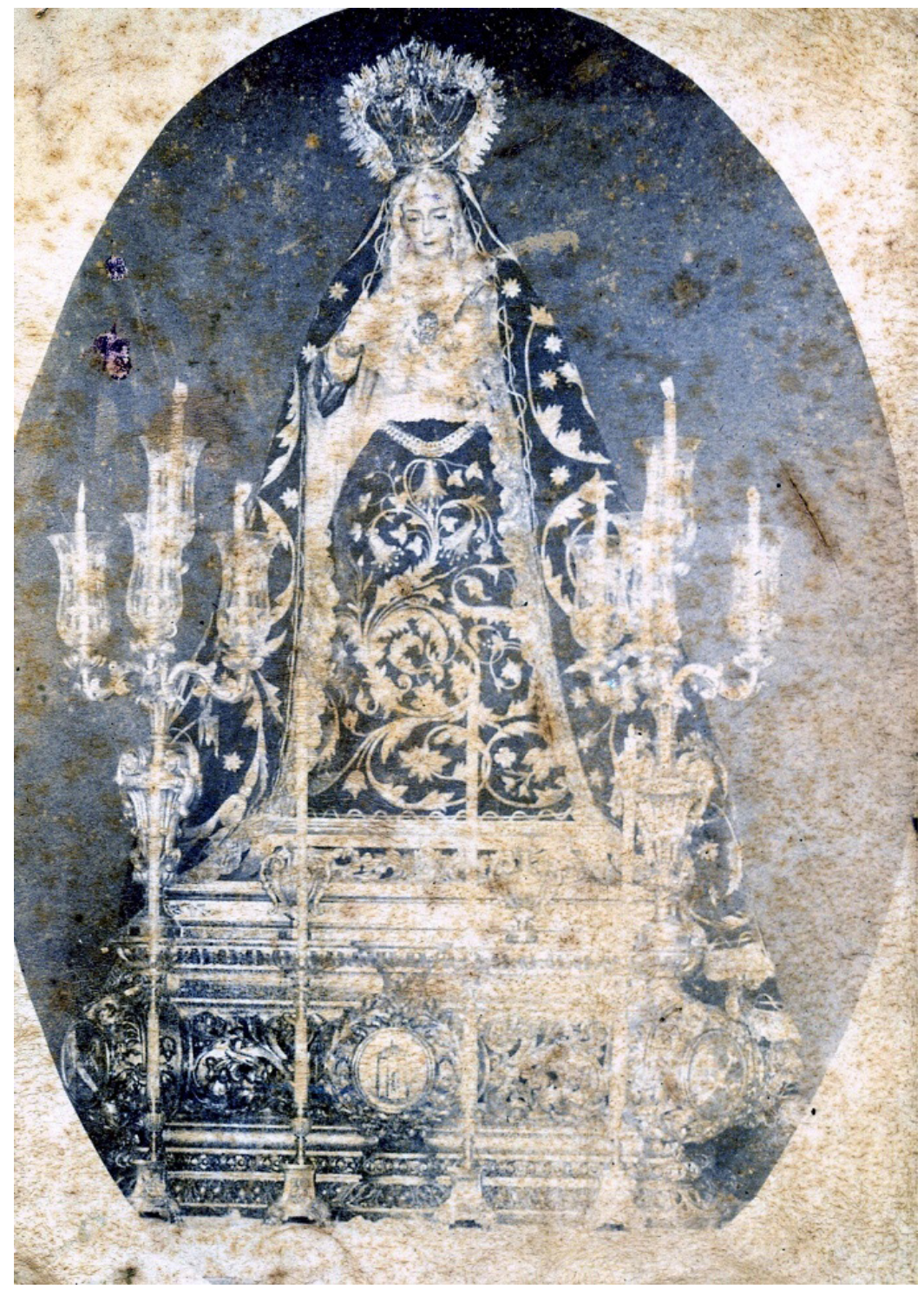

Figura 5. Fotografía de una dolorosa que concuerda con los rasgos fundamentales de la Virgen de la Esperanza, cuya identificación es posible aunque compleja debido a la ausencia de elementos relacionable en el ajuar asociado. 


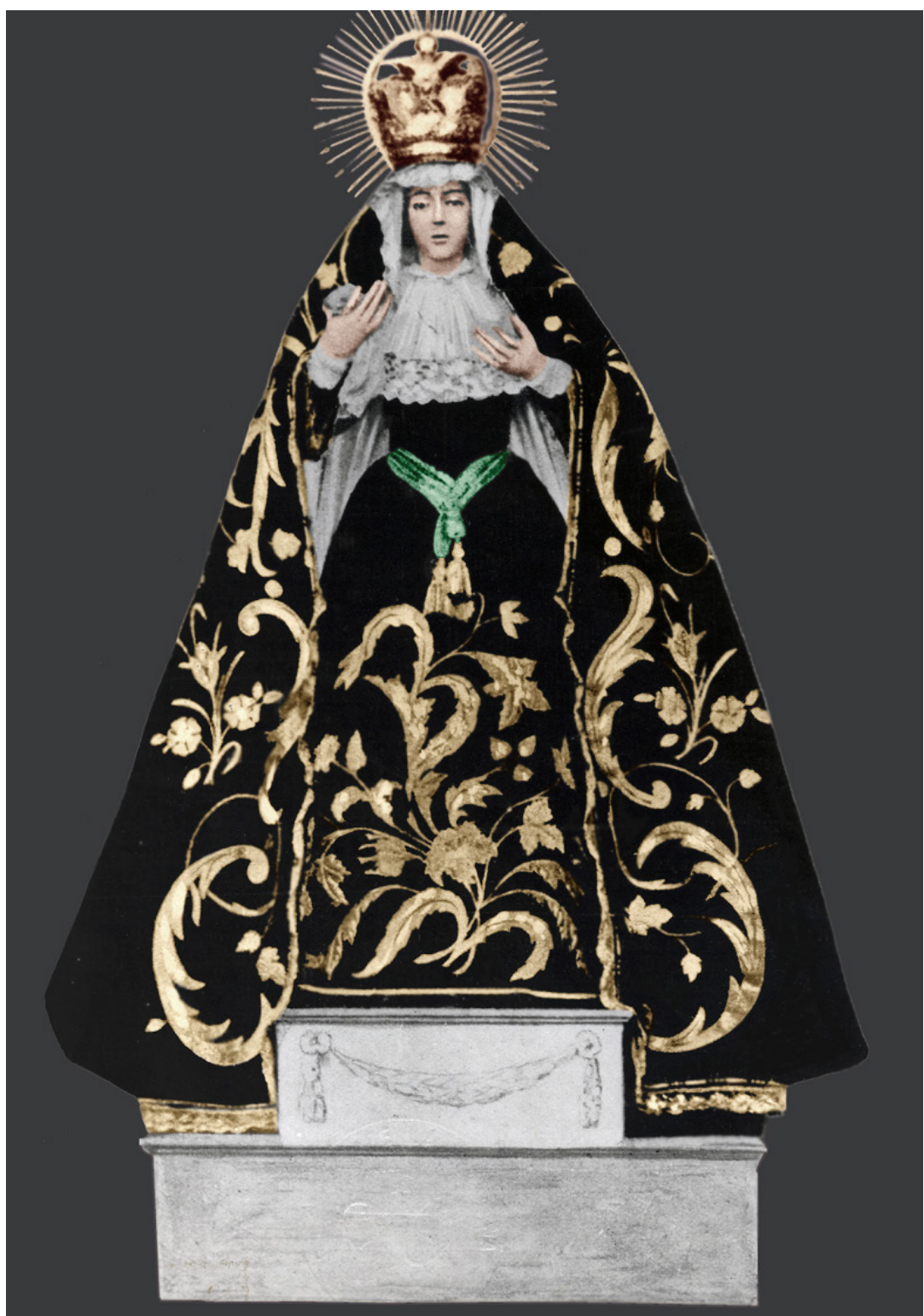

Figura 6. Virgen de la Esperanza en una fotografía anterior a la restauración asesorada por Virgilio Mattoni. 


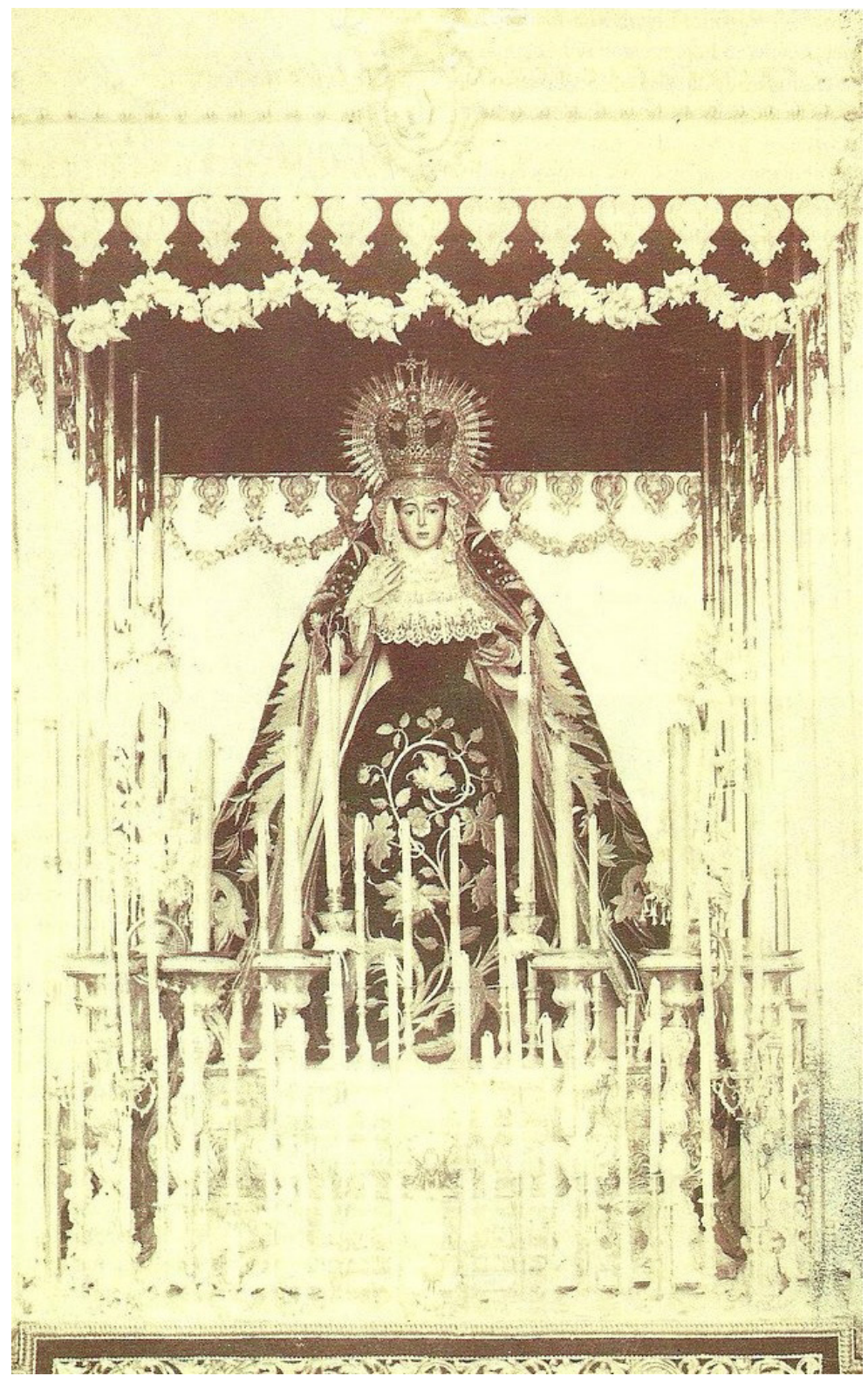

Figura 7. Fotografía de la Virgen de la Esperanza fechada en 1879 a 1882. 


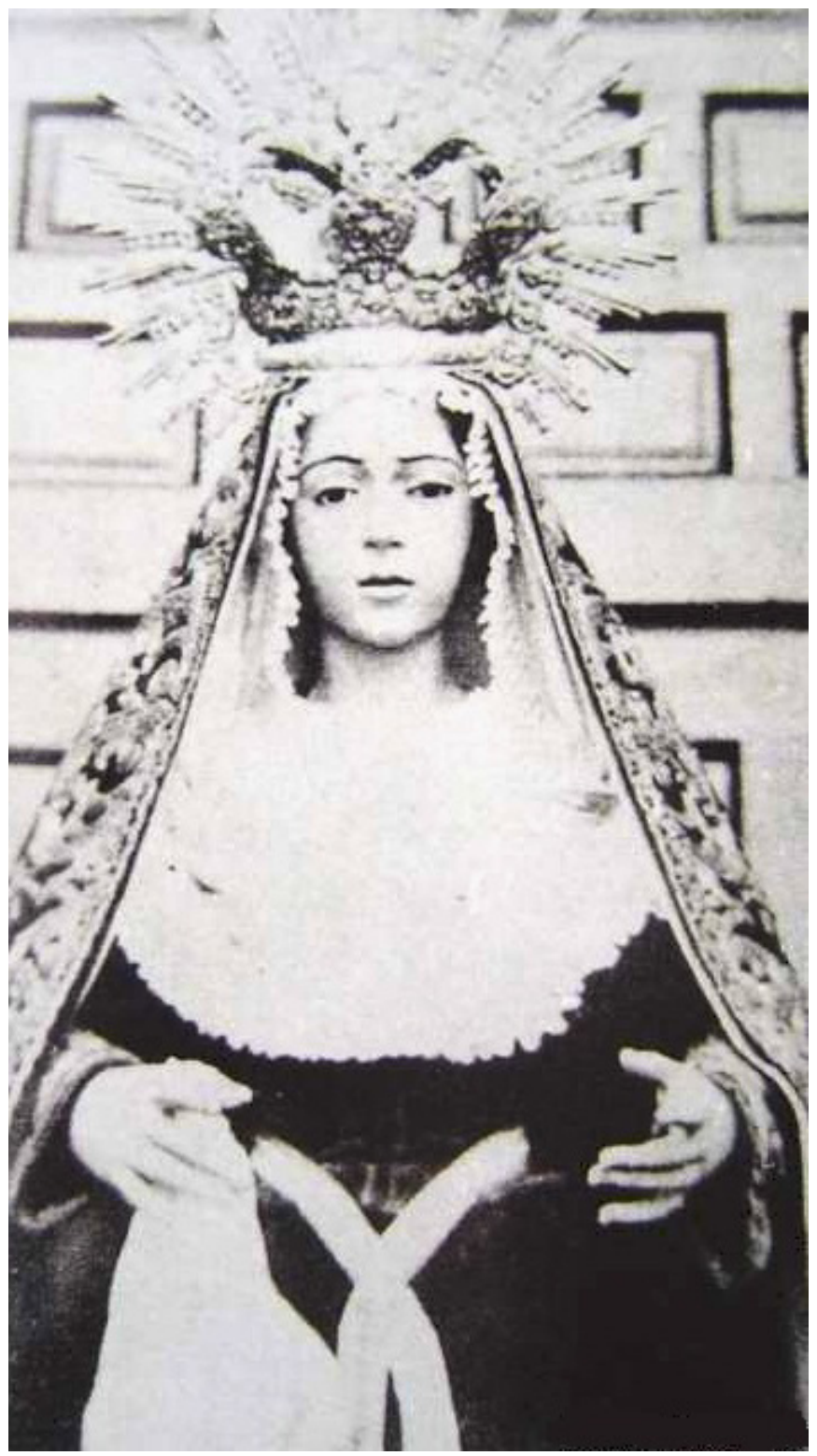

Figura 8. La fotografía muestra muy bien la decisión de elevar la cara de la Virgen con un ligero desplazamiento del torso sobre el candelero, reforma reversible asesorada por Virgilio Mattoni en la restauración del año 1881. 


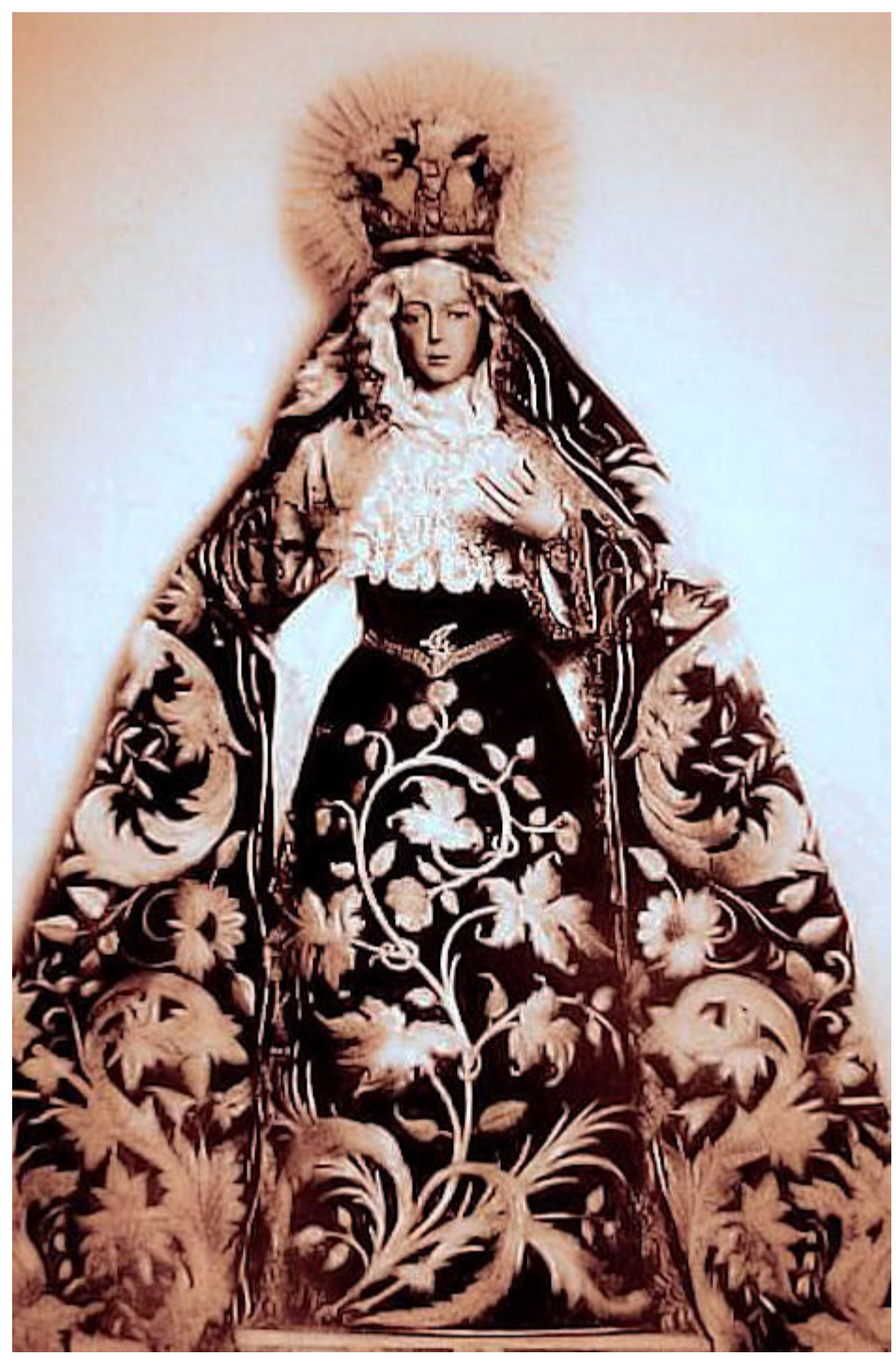

Figura 9. La restauración efectuada por Emilio Pizarro con el asesoramiento del pintor Virgilio Mattoni respetó la talla original de la Virgen de la Esperanza, como muestra esta fotografía fechada entre 1881 y 1890. 


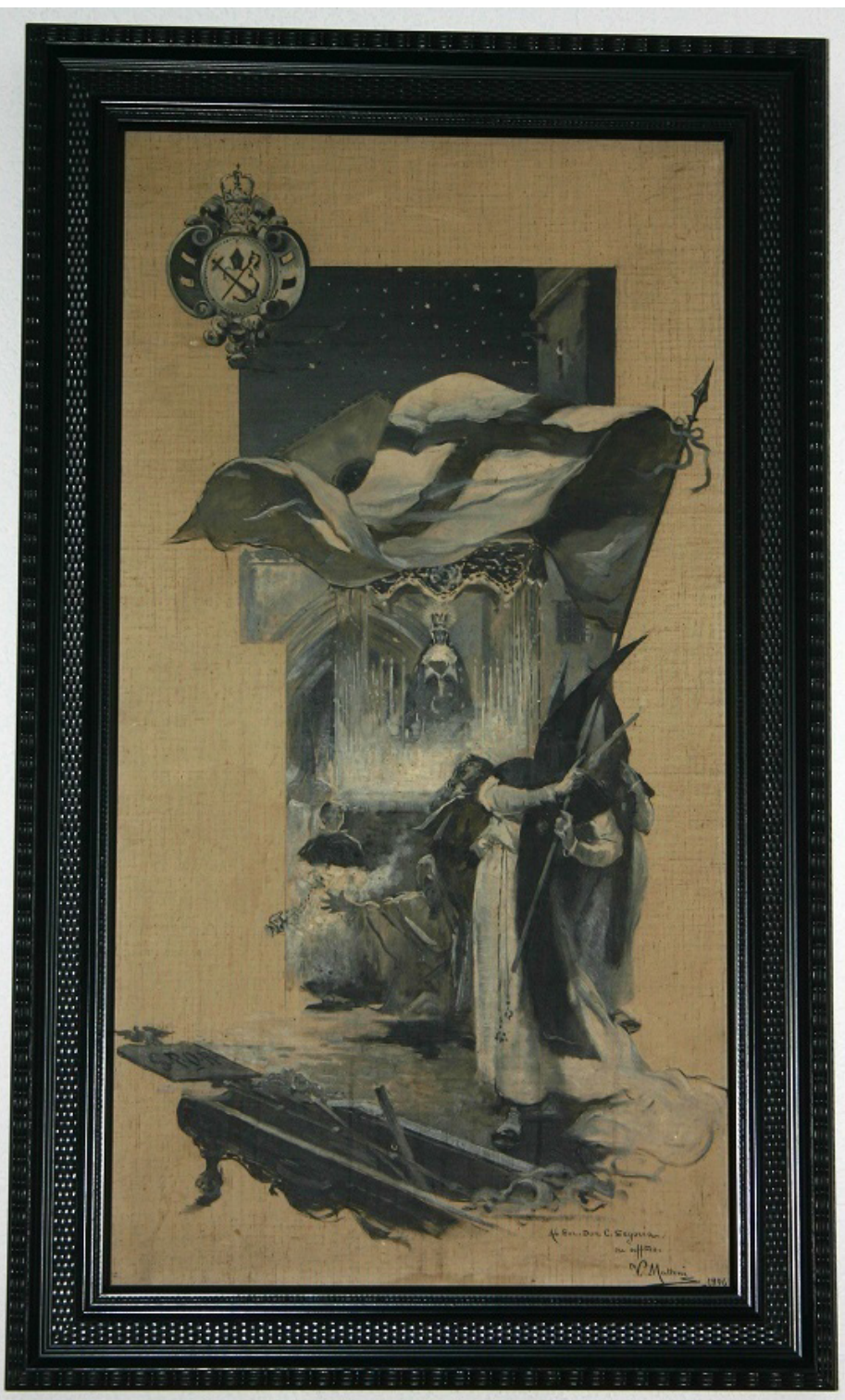

Figura 10. Virgilio Mattoni, La Virgen de la Esperanza saliendo de la Iglesia de San Gil, 1896. 